\title{
Integrated Vehicle Health Management: Essential Reading
}




\title{
Other SAE books of interest:
}

\author{
Integrated Vehicle Health Management: \\ Perspectives on an Emerging Field \\ Edited by lan K. Jennions \\ (Product Code: R-405)
Integrated Vehicle Health Management:
Business Case Theory and Practice
Edited by lan K. Jennions
(Product Code: R-414)
Integrated Vehicle Health Management:
The Technology
Edited by lan K. Jennions
(Product Code: R-429)

\author{
For more information or to order a book, contact: \\ SAE International \\ 400 Commonwealth Drive \\ Warrendale, PA 15096-0001 USA \\ Phone: 877-606-7323 (U.S. and Canada only) \\ or 724-776-4970 (outside U.S. and Canada) \\ Fax: 724-776-0790; \\ Email: CustomerService@sae.org; \\ Website: books.sae.org
}




\section{Integrated Vehicle Health Management: Essential Reading}

Edited by lan K. Jennions

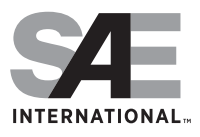

Warrendale, Pennsylvania, USA 


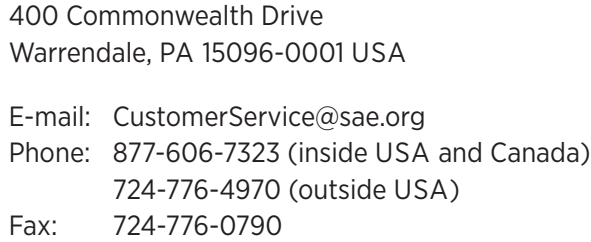

Copyright $\subset 2013$ SAE International. All rights reserved.

No part of this publication may be reproduced, stored in a retrieval system, distributed, or transmitted, in any form or by any means without the prior written permission of SAE International. For permission and licensing requests, contact SAE Permissions, 400 Commonwealth Drive, Warrendale, PA 15096-0001 USA; e-mail: copyright@sae.org; phone: 724-772-4028; fax: 724-772-9765.

ISBN 978-0-7680-8067-4

Library of Congress Catalog Number 2013948307

SAE Order Number PT-162

DOI 10.4271/PT-162

Information contained in this work has been obtained by SAE International from sources believed to be reliable. However, neither SAE International nor its authors guarantee the accuracy or completeness of any information published herein and neither SAE International nor its authors shall be responsible for any errors, omissions, or damages arising out of use of this information. This work is published with the understanding that SAE International and its authors are supplying information, but are not attempting to render engineering or other professional services. If such services are required, the assistance of an appropriate professional should be sought.

\section{To purchase bulk quantities, please contact}

SAE Customer Service

e-mail: CustomerService@sae.org

phone: 877-606-7323 (inside USA and Canada)

724-776-4970 (outside USA)

fax: $\quad 724-776-0790$

Visit the SAE International Bookstore at

books.sae.org 


\section{Table of Contents}

Introduction

Papers

Embedded Diagnostics and Prognostics for Future Vehicles (870397), Furno, V. E., and Resnick, H. L.

Integrated Vehicle Health Management for Aerospace Systems-A Need for Robust and Smart Fluid Components (942167), Gormley, T. J., Vesperman, C., and Engle, J.

Distributed Health Management Systems Technology for Future Propulsion Control Systems (912167), Wald, J., Schoess, J., and Hadden, G.

Engines

Monitoring the Progression of Micro-Pitting in Spur Geared Transmission Systems Using Online Health Monitoring Techniques (2011-01-2700), Onsy, A., Shaw, B. A., and Zhang, J.

Very High Frequency Monitoring System for Engine Gearbox and Generator Health Management (2007-01-3878), Watson, M. J., Byington, C. S., and Behbahani, A. ...... 59

Refinements to Mechanical Health Monitoring Algorithms (2012-01-2096), Hickenbottom, C., Kim, K., and Uluyol, O.

Certification of Engine Health Management Systems: Guidelines for Selecting Software Assurance Levels (2011-01-2704), Rajamani, R., and Waters, N.

Airframes

Structural Health Management: Systems Design Approach (2009-01-3230), Ihn, J-B, Davis, C., and Haugse, E.

A Validation Methodology for Structural Health Monitoring (2011-01-2608),

Azzam, H., and McFeat, J.

Ground Based Vehicle Health Monitoring for Lifecycle Cost Reduction (2003-01-2981),

Schaefer, L

Smart Monitoring System for Aircraft Structures (2011-01-2714), Rouet, V., and Foucher, B. 
Electrical Power Systems

A Framework for Developing an EPS Health Management System (2010-01-1725),

Hernandez, L., Mullins, M., Morris, C., and Keller, K.

Aircraft Electrical Power Systems Prognostics and Health Management (AEPHM)

(2004-01-3162), Keller, K., Amo, A. D., and Jordan, B.

Integrating Electrical Prognostics and Monitoring into an Electronic Power

Distribution System (2009-01-3190), Ballas, M., and Potter, F.

A Model-Based Development Approach for a Diagnostic System for a

Multifunctional Fuel Cell System (2011-01-2702), Modest, C., Schories, K., Lüdders,

H. P., and Thielecke, F.

Supporting Systems

Battery Diagnostic and Prognostics for Aviation Batteries Via a Passive Diagnostic Device (2012-01-2239), James, J. E.

Electrochemical Testing at SAFT to Support Health Prognostication Management for Aviation (2009-01-3191), Rickman, S., Guseynov, T., Nechev, K., Kumbar, N., and Hurley, M.

An Overview of Electrically Powered Control Actuation Health Management (2010-01-1746), Schroeder, J. B., and Chen, R.

Health Assessment of Liquid Cooling System in Aircrafts: Data Visualization, Reduction, Clustering, and Classification (2012-01-2106), Najjar, N., Sankavaram, C., Hare, J., Gupta, S., Pattipati, K., Walthall, R., and D'Orlando, P.

Architecture

Sensory Prognostics and Management System (SPMS) (2012-01-2095), Keller, K. J., Maggiore, J., Safa-Bakhsh, R., Rhoden, W., and Walz, M.

Creating a System Architecture for a Vehicle Condition-Based Maintenance System (2012-01-2097), Shao, G., Goldstein, D., Kim, K., Nwadiogbu, E., Proenza, R., Tran, M., and Williams, D.

A Hierarchical Reasoning Structure to Support Aerospace IVHM (2011-01-2665),

Roemer, $\mathrm{M}$. 223 